\title{
Adaptations of lichens to conditions in tropical forests of South-East Asia and their taxonomic implications
}

\author{
P.A. Wolseley ${ }^{1}$, D.L. Hawksworth ${ }^{1,2}$
}

\section{Key words}

algae

Ascomycota

bioindication

coevolution

symbiosis

\begin{abstract}
Lichens are fungi with a specialized nutritional mode involving algae, or cyanobacteria, or both. Classification is based on the fungal partner, and around 13500 species are known. The association is ancient, and the first ascomycete fungi with fruit bodies may have been lichenized. Adaptations to tropical habitats include extensive utilization of trentepohlioid algae, the production of large multi-celled spores capable of forming numerous germ tubes, and water-repellant hydophobins coating internal cell walls. Many tropical groups lack modern monographs and numerous new species are discovered in detailed studies. Lichens merit more attention in the tropics as bioindicators of habitat disturbance.
\end{abstract}

Published on 30 October 2009

\section{WHAT IS A LICHEN?}

Lichens are an ecological, not a systematic, group consisting of fungi which have developed a specialised nutritional mode by combining with green algae and/or cyanobacteria to obtain their carbohydrates, and forming a structure in which the fungal tissues envelop their photosynthetic partners (Hawksworth 1988). They can be interpreted as independent ecosystems rather than organisms (Farrar 1976). About one-fifth of all known extant fungal species form obligate mutualistic symbiotic associations with green algae, cyanobacteria or both photobionts, amounting to c. 13500 fungal species (Sipman \& Aptroot 2001), and these combine with c. 25 genera of algae and 15 genera of cyanobacteria (Honegger 2001). The symbiosis results in a stable self-supporting association with characteristic features, and for which the name of the fungus is used; the photosynthetic partner has a separate name. The dual organism per se, that we call a lichen, strictly still has no independent name (Hawksworth 1997), and lichens are classified in the general fungal system according to the nature of the fungal partner.

Although this interpretation is now accepted, the controversy over whether lichens were dual organisms or not occupied some of the most famous botanists in Europe for c. quarter of a century following Schwendener's announcement in 1867 that lichens were a subdivision of fungi where ascomycetes were parasitic on algae. But, as Thwaites remarked in 1877, this was unlike parasitism as the algae remained in remarkably good health when associated with a fungus in a lichen (Mitchell 2002). The associations are a result of coevolution, as many of the partners involved do not occur independently in nature. Indeed, one of the commonest algal partners in lichens, Trebouxia species, do not appear to occur in a free-living state. Ahmadjian (2002) suggests that the fungal partner provides the alga with essential nutrients that enable it to thrive within the lichen, but more importantly it provides protection so that the algae can grow in habitats which they would not otherwise be able to exploit. The partners can often be grown separately

\footnotetext{
1 Department of Botany, The Natural History Museum, Cromwell Road, London SW7 5BD, United Kingdom.

2 Departamento de Biologia Vegetal II, Facultad de Farmacia, Universidad Complutense de Madrid, Plaza Ramon y Cajal, Ciudad Universitaria, Madrid 28040, Spain
}

from each other in artificial culture, but then only exceptionally form any sexual reproductive structures. Langenstein \& Oberwinkler (1996) showed that in the lichenized basidiomycete now known as Lichenomphalia umbellifera neither the fungus nor the green algal partner Coccomyxa thrived when cultured independently.

\section{HOW ANCIENT IS THIS ASSOCIATION?}

Using sequences from fungal DNA from lichenized and nonlichenized fungi, Lutzoni et al. (2001) demonstrated that lichenization in Ascomycota was ancestral and had been lost many times in the evolution of modern ascomycete groups. Eriksson (2005) has even suggested that the first ascomycetes with fruit bodies may well have been lichenized. Furthermore, the biology can vary within a genus or species, something first proved molecularly by Wedin et al. (2004) who demonstrated that three Stictis species (non-lichenized saprophytes of decaying wood) and three Conotrema species (lichens on Poplulus bark) represented the same three species which switched biology depending on the substrate when an appropriate alga was available. There are now over 50 genera known which include both lichens and fungi with other life-styles (Hawksworth 2005). Molecular work has also shown that the traditional division of life-forms into crustose, foliose and fruticose has little to do with phylogenetic relationships, with most orders, many families, and even some genera, including lichens comprising representatives with different life-forms (Grube \& Hawksworth 2007). Thus, in the common tropical family Roccellaceae, crustose and fruticose life-forms are closely related. Furthermore, the same fungal species, when combined with cyanobacteria as opposed to green algae, may produce morphologically different morphotypes which have in the past sometimes been even placed in different genera, for example Sticta felix also in Dendriscocaulon (James \& Henssen 1976). There are many similar cases where two or more morphotypes involving the same fungus and different photobionts occur in rainforest genera, especially Pseudocyphellaria and Sticta (Green \& Lange 1991).

(c) 2009 Nationaal Herbarium Nederland

You are free to share - to copy, distribute and transmit the work, under the following conditions:

Attribution: You must attribute the work in the manner specified by the author or licensor (but not in any way that suggests that they endorse you or your use of the work). 


\section{THE PHOTOBIONT}

The photosynthetic partners, the photobionts, of lichens belong in three main groups, of which two are chlorococcoid green algae comprising either Trentepohliales (which scratch orange) or Trebouxiales (which scratch green when wet), the other group being cyanobacteria (dark grey when wet). Photobionts are not known to reproduce sexually within the lichens, but unlike the fungal partner many of the genera are also known in a free-living state, apart from Trebouxia. However, it is not always clear whether free-living algae and photobionts of the same genus represent the same species.

Trentepohliales occur free-living on twigs, bark, and shaded damp rocks, and are widespread in tropical and subtropical environments. Many tropical lichens have photobionts in Trentepohliales, and the majority of these lichens reproduce sexually, rarely producing vegetative propagules. As the free-living species are readily available, lichen ascospores can germinate and find an appropriate photobiont (Chapman \& Waters 2002). However, Tucker et al. (1991) showed that the algal partner is not always the same species or even the same genus in Trentepohliaceae. For instance, Graphis scripta was found to have Phycopeltis in tropical Louisiana, Trentepohlia umbrina in France, T. annulata in Hungary, and T. lagenifera in Japan.

In contrast, lichenized species with Trebouxia as photobiont reproduce vegetatively to a large extent by either thallus fragments or specialized propagules containing both partners, such as soredia, isidia, or phyllidia. Fungus species that reproduce only sexually and associate with Trebouxia must obtain their algal partner from another lichen following ascospore germination. This form of competition is known to occur between different species and genera (Friedl 1987, Ott 1987, Hawksworth 1988). Despite this seeming limitation, species of Parmeliaceae and Physciaceae are abundant in well-lit sites in tropical and temperate environments, and especially in disturbed environments, and so it is evident that dispersal and establishment are not a problem in practice. However, it is highly probable that invertebrates in the canopy, especially mites and termites, which are frequently coated in lichen propagules are a major distributor in tropical canopies (Lowman \& Nadkarni 1995). Meier et al. (2002) showed that faecal pellets of lichenivorous mites can contain viable cells of the lichen-forming ascomycete Xanthoria parietina and the green algal photobiont Trebouxia arboricola. Furthermore, propagules from different individuals of the same species, or of different species within a genus, may coalesce so that an apparently single lichen may be genetically heterogeneous (Ott 1987, Shaw 1992).

Lichens with Trentepohliaceae as photobiont are abundant in humid tropical regions, represented mainly by the families Arthoniaceae, Graphidaceae, Pyrenulaceae, Thelotremataceae, and Trichotheliaceae. Lichens with Trebouxia as photobiont dominate tropical regions with an alternating wet and dry period, and include macrolichens in Parmeliaceae, and macrolichens and crusts in Bacidiaceae (syn. Ramalinaceae), Physciaceae, and Pertusariaceae. Families with cyanobacteria and/or chlorococcoid algae include Lobariaceae and Collemataceae and are more frequent in humid forests. The shift to Trebouxia dominated families may occur with increasing dryness and/or disturbance as caused by fire in Thailand (Fig. 1a), and to Trentepohlia dominated families with increasing humidity and shading. In the equatorial forests of SE Kalimantan, increasing management regimes are associated with loss of bryophytes and trentepohlioid lichens and an increase in trebouxioid lichen cover (Fig. 1b).

\section{THE MYCOBIONT}

Tropical lichens belong mainly in Ascomycota, except for a few Basidiomycota (e.g. Dictyonema spp.) not considered here but which continue to be discovered (Nelsen et al. 2007). Until the development of molecular methods, ordinal and family concepts depended mainly on the characters of the reproductive bodies of the fungus, especially the fruit bodies and asci. The fruiting body of all lichenised Ascomycota is an ascoma which may be an open saucer-like apothecium, a flask shaped perithecium, or some form of stroma with included asci. Within these bodies, asci are produced with walls that have one or two functional layers, amyloid or not, with various apical structures (Hafellner 1988) and discharge methods (Honegger 1982). These contain one to numerous ascospores, but most commonly eight, which may be hyaline or dark coloured, simple, septate or muriform, and with or without ornamentation or gelatinous sheaths.

However, molecular phylogenetic methods have shown that many of the features based on thallus growth-form, fruit-body type, and fine differences in ascus types cannot be maintained as ordinal, family, or in some cases generic characters, so that an extensive re-evaluation of traditional groupings has become necessary (Miadlikowska et al. 2007, Grube \& Hawksworth 2007).

The most immediate challenge for lichenologists in the tropics, both for traditional and for molecular taxonomists, is how to address the number of undescribed species. For example, Thelotremataceae are a conspicuous family of tropical crustose lichens, and were reported by Hale (1981) to include 11 genera and 536 species worldwide. However, following her PhD, based on morphology and chemistry of Thelotremataceae in Thailand and parts of Malaysia, Homchantara (Homchantara \& Coppins 2002) described 30 new species out of a total of 116 investigated in three genera as a result of only modest collecting in the country. In the case of Papua New Guinea, Aptroot et al. (1997) described 298 species, with 269 new to the island
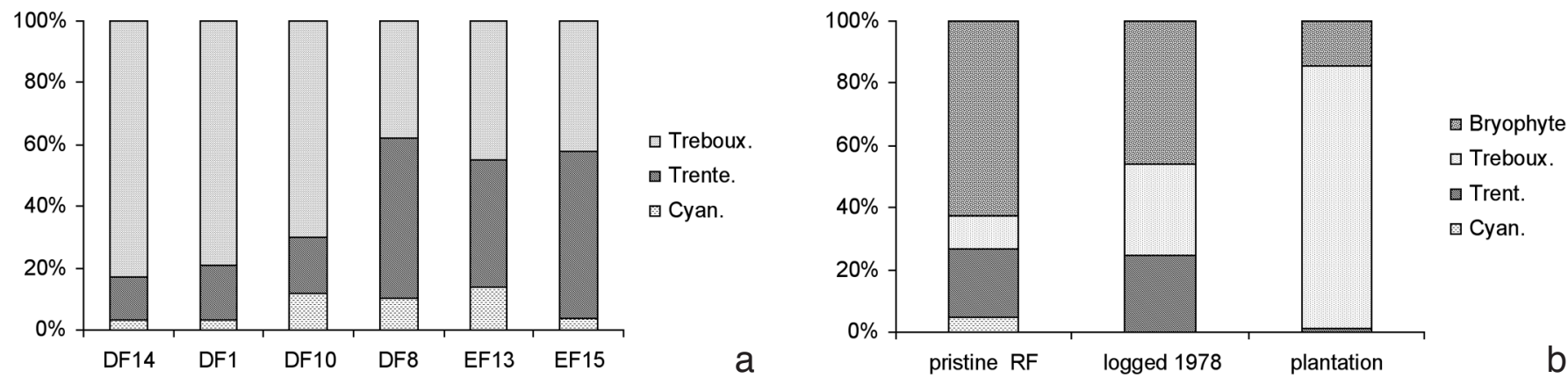

Fig. 1 a. Percentage frequency of cyanobacterial (Cyan.), trebouxioid (Treboux.) and trentepohliod (Trente.) lichen photobionts in deciduous (DF) and evergreen (EF) forests in Thailand - from open savanna forest (DF1) to fire protected forest for 23 years (DF8), to seasonal evergreen forest (EF 13 \&15). From Wolseley (1997). — b. Percentage frequency of lichen photobionts and bryophytes in equatorial rain forest in Kalimantan under different management regimes (Wolseley et al. 2007). 
and 89 new to science as a result of collecting on only a limited number of expeditions. This suggests that there are many more species in the tropics to be described.

Up until now, relatively few tropical lichen species have been represented in molecular phylogenies, but this is starting to change and their inclusion may well alter systematic perceptions. For example, Staiger (2002) investigated another family of mainly tropical crusts, Graphidaceae, comprising c. 22 genera and c. 1000 species. Both Thelotremataceae and Graphidaceae have septate to muriform ascospores, that may be hyaline or brown, but Graphidaceae were distinguished by elongate ascomata that were often carbonised while Thelotremataceae had rounded apothecia, often deeply immersed, a separating true exciple, sometimes appearing perithecia-like with the spores released through an ostiole. However, there are also intermediate types between these two families and a recent molecular phylogeny places genera of Thelotremataceae within Graphidaceae (Staiger et al. 2006). Genera in Graphidaceae had traditionally been separated on muriform or septate, brown or hyaline spores, but one clade including all Phaeographis species (with septate brown spores) also includes species with hyaline and muriform spores and species with stromata. Muriform spores are widespread in tropical genera in many families, and this may be regarded as an adaptation to tropical conditions facilitating rapid establishment through the production of multiple germ tubes on a substrate where competition for space is extreme (Sangvichien pers. comm.; Fig. 2). Yet, representatives of widespread tropical genera such as Graphina and Phaeographina are conspicuously absent from current molecular phylogenies of Graphidaceae, as are representatives of species from the Old World tropics. Where phylogenies of these huge families do not include Old World tropical components, it would seem pragmatic to maintain traditional generic separations until we have more molecular evidence. This was done by many European lichenologists for Parmeliaceae until molecular data were overwhelming (Hawksworth et al. 2008). In the meantime, the main focus for tropical lichenologists needs to be the collection, description, sequencing, and where possible culturing, of tropical lichen biodiversity before it disappears.

\section{CHEMICAL PRODUCTS: \\ FUNCTION AND TAXONOMIC APPLICATION}

Lichens produce over 630 unique chemical products, and also a small number that are also found in allied non-lichenized fungi, or in rare cases plants (Elix 1996). With increasingly sensitive technologies, more and more compounds are being detected and described and their quantities estimated in a range of ecological conditions (Huneck \& Yoshimura 1996). These compounds are now known to be produced by the fungus alone, and have been shown to have a number of important functions in the lichen thallus including antibiotic (e.g. usnic and roccellic acids), anti-fungal, anti-herbivore (e.g. atranorin, usnic and vulpinic acids), and anti-exposure and UV-B radiation (e.g. usnic acid, anthraquinones, melanins) properties (Lawrey 1986, Rikkinen 1995). Chemical products, often highly coloured, may also be accumulated in substantial amounts in the epithecium (upper layers) of an apothecium where they protect the sporebearing tissue over several years of spore production. Other compounds may play a crucial role in protecting slow-growing crusts from invasive fungi or from other lichens throughout their long lives. In Thailand, where fire occurs frequently in dry and evergreen tropical monsoon forests, causing the death of lichens on the trunks of dipterocarps, this is followed by colonisation of the dead thallus surface by other lichens which were unable to establish on the pre-existing living thallus (Wolseley \& Aguirre-Hudson 1997).

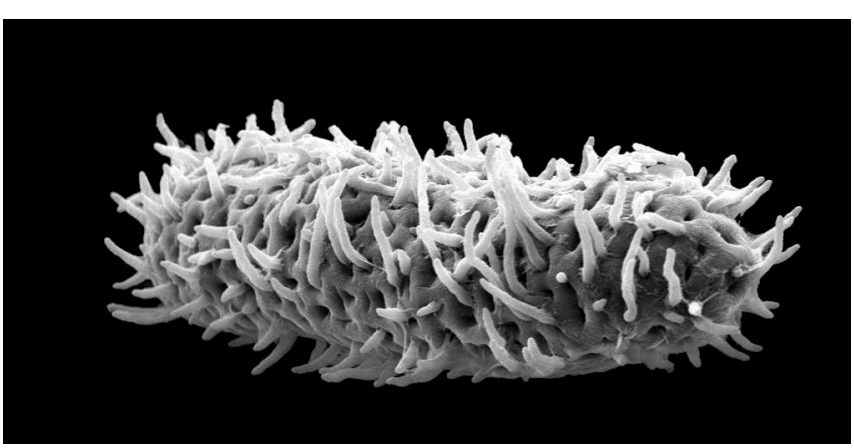

Fig. 2 Germinating ascospore of Cyclographina platyleuca showing multiple germ-tubes from muriform spore; scanning electron micrograph. Photo: Ek Sangvichien.

Another important feature that has adaptative value in tropical rainforest conditions is the coating of the cell walls of the hyphae inside the lichen thalli with hydrophobins, cysteine-rich water-repelling proteins that protect the thallus and algal cells from becoming waterlogged (Wösten \& Wessels 1997, Dyer 2002, Trembley et al. 2002). This adaptation is likely to be especially important in leprose lichens, which lack a covering fungal layer (i.e. an upper cortex), such as species of Lepraria, Chrysothrix, and Crocynia.

\section{OBSTACLES IN TROPICAL TAXONOMY}

Following the numerous 19th century explorations of tropical forests in the Old World, there was a tendency for lichenologists to describe lichens from different parts of the tropics as new species. Many of these specimens are in European museums and other institutions, and have not yet been reassessed since their original description. The absence of modern monographs of numerous tropical genera and families also means that species are often difficult to name without consulting original species descriptions and examining type collections in Europe, and this is further compounded by there being many as yet undescribed species. This problem is illustrated by a recent paper reporting c. 300 new records of lichens mainly from northern Thailand, based on collections in the Natural History Museum (BM) in London and Adviesbureau voor Bryologie en Lichenologie $(A B L)$ in The Netherlands; of these, six were first records for the Northern Hemisphere and 12 were new to science (Aptroot et al. 2007). However, throughout much of Malesiana, the absence of descriptions and appropriate regional keys, and the absence of substantial in-country reference collections and libraries, are major obstacles to both the training of regional systematic researchers and those concerned with the conservation of biodiversity in the region (Coppins \& Wolseley 2002).

In view of the value of lichens as bioindicators of ecological continuity and of changing environmental conditions in tropical forests (Coppins \& Wolseley 2002, Hawksworth et al. 2005, Wolseley et al. 2007), the development of national capacities in lichenology merits heightened attention by those concerned with science policy and the development of infrastructures in the Flora Malesiana region.

\section{REFERENCES}

Ahmadjian V. 2002. Trebouxia: reflections on a perplexing and controversial lichen photobiont. In: Seckbach J (ed), Symbiosis: mechanisms and model systems. Cellular origin and life in extreme habitats: $375-383$. Kluwer Academic Publishers, Dordrecht.

Aptroot A, Diederich P, Sérusiaux E, Sipman HJM. 1997. Lichens and lichenicolous fungi from New Guinea. Bibliotheca Lichenologica 64: 1-220. Cramer, Berlin, Stuttgart. 
Aptroot A, Saipunkaew W, Sipman HJM, Sparrius LB, Wolseley PA. 2007. New lichens from Thailand, mainly microlichens from Chiang Mai. Fungal Diversity 24: 75-134.

Chapman RL, Waters DA. 2002. Lichenization of the Trentepohliales. In: Seckbach J (ed), Symbiosis: mechanisms and model systems. Cellular origin and life in extreme habitats: 361-371. Kluwer Academic Publishers, Dordrecht.

Coppins BJ, Wolseley PA. 2002. Lichens of tropical forests. In: Watling R, Frankland JC, Ainsworth AM, Isaac S, Robinson CH (eds), Tropical mycology: Volume 2, Micromycetes: 113-131. CABI Publishing, Wallingford.

Dyer PS. 2002. Hydrophobins in the lichen symbiosis. New Phytologist 154: $1-14$

Elix JA. 1996. Biochemistry and secondary metabolites. In: Nash III TH (ed), Lichen biology: 154-180. Cambridge University Press, Cambridge.

Eriksson OE. 2005. Ascomyceternas ursprung och evolution - Protolicheneshypotesen. Svensk Mykologisk Tidskrift 26: 22-33.

Farrar JF. 1976. The lichen as an ecosystem: observation and experiment. In: Brown DH, Hawksworth DL, Bailey RH (eds), Lichenology: Progress and problems: 385-406. Academic Press, London.

Friedl T. 1987. Thallus development and phycobionts of the parasitic lichen Diploschistes muscorum. Lichenologist 19: 183-191.

Green TGA, Lange OL. 1991. Ecophysiological adaptations of the lichen genera Pseudocyphellaria and Sticta to south temperate rainforests. Lichenologist 23: 267-282.

Grube M, Hawksworth DL. 2007. Trouble with lichen: the evaluation and re-interpretation of thallus form and fruit body types in the molecular era. Mycological Research 111: 1116-1132.

Hafellner J. 1988. Principles of classification and main taxonomic groups. In: Galun M (ed), CRC handbook of lichenology. Volume III: 41-52. CRC Press, Boca Raton, Florida.

Hale ME. 1981. A revision of the lichen family Thelotremataceae in Sri Lanka. Bulletin of the British Museum (Natural History), Botany 8: 227-332.

Hawksworth DL. 1988. The variety of fungal-algal symbioses, their evolutionary significance, and the nature of lichens. Botanical Journal of the Linnean Society 96: 3-20.

Hawksworth DL. 1997. Raffaele Ciferri, the crisis precipitated in the naming of lichen-forming fungi, and why lichens have no names. Archivo Geobotanioco 3: 3-9.

Hawksworth DL. 2005. Life-style choices in lichen-forming and lichen-dwelling fungi. Mycological Research 109: 135-136.

Hawksworth DL, Blanco O, Divakar PD, Ahti T, Crespo A. 2008. A first checklist of parmelioid lichens in Europe and some adjacent territories, adopting revised generic circumscriptions and with indications of species distributions. Lichenologist 40: 1-21.

Hawksworth DL, Iturriaga T, Crespo A. 2005. Liquenes como bioindicatores inmediatos de contaminaciónn y cambios medio-ambientales en los trópicos. Revista Iberoamericana de Micología 22: 71-82.

Homchantara N, Coppins BJ. 2002. New species of the lichen family Thelotremataceae in SE Asia. Lichenologist 34: 113-140.

Honegger R. 1982. Ascus structure and function, ascospore delimitation, and phycobiont cell wall types associated with the Lecanorales (lichenized ascomycetes). Journal of the Hattori Botanical Laboratory 52: 417-429.

Honegger R. 2001. The symbiotic phenotype of lichen-forming ascomycetes. In: Hock B (ed), The mycota IX. Fungal associations: 165-188. SpringerVerlag, Berlin, Heidelberg.

Huneck S, Yoshimura I. 1996. Identification of lichen substances. SpringerVerlag, Berlin, Heidelberg

James PW, Henssen A. 1976. The morphological and taxonomic significance of cephalodia. In: Brown DH, Hawksworth DL, Bailey RH (eds), Lichenology: Progress and problems: 27-77. Academic Press, London.

Langenstein B, Oberwinkler F. 1996. Establishment and development of the basidiolichen Botrydina (Omphalina ericetorum (Pers.) M. Lange) in vitro. In: Book of abstracts of the 3rd IAL Symposium. Progress and problems in lichenology in the nineties: 93. Salzburg, Austria.
Lawrey JD. 1986. Biological role of lichen substances. Bryologist 89: 111122.

Lowman M, Nadkarni X. 1995. Forest Canopies. Academic Press, San Diego.

Lutzoni F, Pagel M, Reeb V. 2001. Major fungal lineages are derived from lichen symbiotic ancestors. Nature 411: 937-940.

Meier FA, Scherrer S, Honegger R. 2002. Faecal pellets of lichenivorous mites contain viable cells of the lichen-forming ascomycete Xanthoria parietina and its green algal photobiont, Trebouxia arboricola. Biological Journal of the Linnean Society 76: 259-268.

Miadlikowska J, Kauff F, Hofstetter V, Fraker E, Grube M, Hafellner J, Reeb V, Hodkinson BP, Kukwa M, Lücking R, Hestmark G, Otalora MG, Rauhut A, Büdel B, Scheidegger C, Timdal E, Stenroos S, Brodo I, Perlmutter GB, Ertz D, Diederich P, Lendemer JC, May P, Conrad L, Schoch A, Arnold E, Gueidan C, Tripp E, Yahr R, Robertson C, Lutzoni F. 2007, '2006'. New insights into classification and evolution of the Lecanoromycetes (Pezizomycotina, Ascomycota) from phylogenetic analyses of three ribosomal RNA- and two protein-coding genes. Mycologia 98: 1088-1103.

Mitchell ME. 2002. 'Such a strange theory': Anglophone attitudes to the discovery that lichens are composite organisms, 1871-1890. Huntia 11: 193-207.

Nelsen MP, Lücking R, Umaña L, Trest MT, Will-Wolf S, Chaves JL, Gargas A. 2007. Multiclavula ichthyiformis (Fungi: Basidiomycota: Cantharellales: Clavulinaceae), a remarkable basidiolichen from Costa Rica. American Journal of Botany 94: 1289-1296.

Ott S. 1987. Physcia/Xanthoria fungal heterogeneity. Bibliotheca Lichenologica 25: 81-93.

Rikkinen J. 1995. What's behind the pretty colours? A study on the photobiology of lichens. Bryobrothera 4: 1-239.

Shaw AJ. 1992: The evolutionary capacity of bryophytes and lichens. In: Bates JW, Farmer AM (eds), Bryophytes and lichens in a changing environment: 362-380. Clarendon Press, Oxford.

Sipman HJM, Aptroot A. 2001.Where are the missing lichens? Mycological Research 105: 1433-1439.

Staiger B. 2002. Die Flechtenfamilie Graphidaceae. Studien in Richtung einer natürlicheren Gliederung. Bibliotheca Lichenologica 85: 1-526.

Staiger B, Kalb K, Grube M. 2006. Phylogeny and phenotypic variation in the lichen family Graphidaceae (Ostropomycetidae, Ascomycota). Mycological Research 110: 765-772.

Trembley ML, Ringli C, Honegger R. 2002. Differential expression of hydrophobins DGH1, DGH2 and DGH3 and immunolocalization of DGH1 in strata of the lichenized basidiocarp of Dictyonema glabratum. New Phytologist 154: 185-195.

Tucker SC, Matthews SW, Chapman RL. 1991. Ultrastructure of subtropical crustose lichens. In: Galloway DJ (ed), Tropical lichens: their systematics, conservation, and ecology: 171-191. Systematics Association Special Volume. Clarendon Press, Oxford.

Wedin M, Doring H, Gilenstam G. 2004. Saprotrophy and lichenization as options for the same fungal species on different substrata: environmental plasticity and fungal lifestyles in the Stictis-Conotrema complex. New Phytologist 164: 459-465.

Wolseley PA. 1997. Response of epiphytic lichens to fire in tropical forests of Thailand. Bibliotheca Lichenologica 68: 165-176.

Wolseley PA, Aguirre-Hudson B. 1997. Fire in tropical dry forests: corticolous lichens as indicators of recent ecological changes in Thailand. Journal of Biogeography 24: 345-362.

Wolseley PA, Ellis L, Chimonides J. 2007. Corticolous lichen and moss communities in lowland dipterocarp forests under differing management regimes. Bibliotheca Lichenologica 95: 583-603.

Wösten HAB, Wessels JGH. 1997. Hydrophobins, from molecular structure to multiple functions in fungal development. Mycoscience 38: 363-374. 